Article

\title{
Nordic Ties and British Lives? Migrant Capital and the Case of Nordic Migrants Living in London
}

\author{
Saara Koikkalainen \\ Swedish School of Social Sciences, University of Helsinki, 00170 Helsinki, Finland; E-Mail: saara.koikkalainen@helsinki.fi
}

Submitted: 30 June 2019 | Accepted: 19 September 2019 | Published: 19 December 2019

\begin{abstract}
As a hub of finance, art, design and science, the city of London has long attracted migrants interested in study and career opportunities or simply excited about living in an open, global city. Over the last few decades, it has also been a key migration destination for Europeans originating from the Nordic countries. Based on survey data gathered through an online questionnaire, this article focuses on Nordic migrants currently living in London. Since the June 2016 referendum, the Brexit process has forced these voluntary and rather privileged migrants to question their inclusion in British society. This article discusses the role of migrant capital, i.e., the skills and resources created as a result of migration, at a time of uncertainty brought on by Brexit. It examines how these migrants see their position within the social hierarchy of the city and its job market, as well as within the local and transnational networks they maintain to their countries of origin. Their Nordic background is valuable thanks to the cultural capital embodied in their habitus as well as the social capital available via the Nordic networks in UK and transnationally.
\end{abstract}

\section{Keywords}

Brexit; Europe; London; migration; migrant capital; Nordic countries

\section{Issue}

This article is part of the issue "Social Inclusion beyond Borders: Utilization of Migrant Capital in Transnational and Diaspora Communities" edited by Sanna Saksela-Bergholm (University of Helsinki, Finland), Mari Toivanen (University of Helsinki, Finland) and Östen Wahlbeck (University of Helsinki, Finland).

(C) 2019 by the author; licensee Cogitatio (Lisbon, Portugal). This article is licensed under a Creative Commons Attribution 4.0 International License (CC BY).

\section{Introduction}

London has long been Europe's main global city and the driver of British economic growth with a steady demand for migrant labour at all skill levels (e.g., Favell, 2008; Talani, 2018). As a city boasting numerous job opportunities in finance, tourism, advertising, law, art, design, consultancy and research, it has also been one of the key destinations for intra-European migrants. This article discusses the role of migrant capital, i.e., the skills and resources created as a result of migration, in the lives of Nordic migrants living in London under the uncertainty caused by the Brexit referendum of 2016. An estimated 91,000 people born in one of the five Nordic countries (Denmark, Finland, Iceland, Norway, and Sweden) currently live in the UK (Office for National Statistics, 2019a).

Thanks to the victory of the "Leave" campaign in the June 2016 referendum on the British membership of the
$\mathrm{EU}$, the position of London as the migration destination of Europe is changing. While the timetable and manner of the UK's break away from the European Union (EU) is still unclear three years after the referendum, the effects of the decision are already visible, for example, in migration statistics. In the last few years, the UK has been the destination of more than 600,000 migrants each year, while the numbers of people emigrating from the country have remained at around 350,000 per year. This has signified a net immigration rate of 200,000 to 300,000 migrants per year. The proportion of migrants originating from within the EU is decreasing while the number of non-EU arrivals has been rising. EU long-term immigration figures have fallen since 2016, and in 2018 the number of new arrivals was at its lowest since 2013 (Office for National Statistics, 2019b). However, in light of the national statistics of each of the Nordic countries, the popularity of the UK as a migration destination has re- 
mained quite steady for Nordic migrants. In 2018, for example, more than 6,000 Nordic citizens migrated to the UK (Figure 1).

London is an exciting global city that offers the promise of self-discovery via living in a truly multicultural metropolis. For many intra-European migrants, a move to London has been a chance to experience a sense of denationalised freedom (Favell, 2008). However, the uncertainty brought on by the prolonged Brexit process has had an impact on the migrants' lives at multiple levels: for their legal status and rights as residents of the UK, for their work opportunities and career prospects, and for the sense of belonging and feeling of social inclusion in British society. Cassidy, Innocenti, and Bürkner (2018) note that in all of its complexity, the Brexit process has forced both British and EU citizens to revise their everyday sense of belonging. Migrant responses to the outcome of the vote have ranged from initial feelings of shock and panic, followed by pragmatic, adaptive strategies to build a sense of security and continuity (Botterill, McCollum, \& Tyrrell, 2019). In their analysis of the situation, Guma and Dafydd Jones (2019) have examined how Brexit affects EU migrants' rights, settlement and sense of identity and argue that Brexit should be understood as an ongoing process of "othering" and "unsettling." It will thus influence the migrants' social inclusion in the UK, when it is understood as a synonym of terms such as "unity, cohesion, civic engagement [and] togetherness" (Koikkalainen, 2011, p. 454).

The aim of this article is to examine migrant capital via the experiences of Nordic migrants who are contemplating their future as the parameters of belonging and the rules regulating their rights in the UK are changing. Patterns of migrant inclusion and exclusion are not simple processes but are highly differentiated and depend on the features of individual migrants, on structural fac- tors in the country of destination and are impacted by changes in the policies of the country in question (e.g., Carmel \& Cerami, 2011). For EU nationals living in the UK, the Brexit process represents a rupture in time, an exceptional period during which they have to reconsider their personal lives, careers and mobility options. From a temporal perspective, one may hypothesise that this process is different depending on how long one has lived in the UK, how strong the ties one has formed there are, or whether one remains mostly attached to one's country of origin. Do the ways in which one feels social inclusion differ based on the length of stay in the country, and does this matter for migrant capital?

The sections of the article that follow first discuss the different forms of capital and migration, present the data and methods used in this research and then examine cultural and social capital as forms of migrant capital in the case of Nordics living in London.

\section{The Forms of Capital and Migration}

In migration research, Pierre Bourdieu's (1984, 1986) concepts "field," "habitus" and the different "types of capital" have been used in at least two ways: first, to understand the problems of transferring education, skills and expertise from one society or cultural environment to another; and second, to describe the networks and ties forged between different places as a result of migration (e.g., Erel, 2010; Erel \& Ryan, 2019; Nowicka, 2013; Ryan, 2011).

For Bourdieu, all differentiated societies consist of fields or networks of relations that structure our social world: "The social cosmos is made up of a number of such relatively autonomous social microcosms, i.e., spaces of objective relations" (Wacquant, 1989, p. 39). These include the economic, artistic or religious field,

Migrants from the Nordic countries to the UK

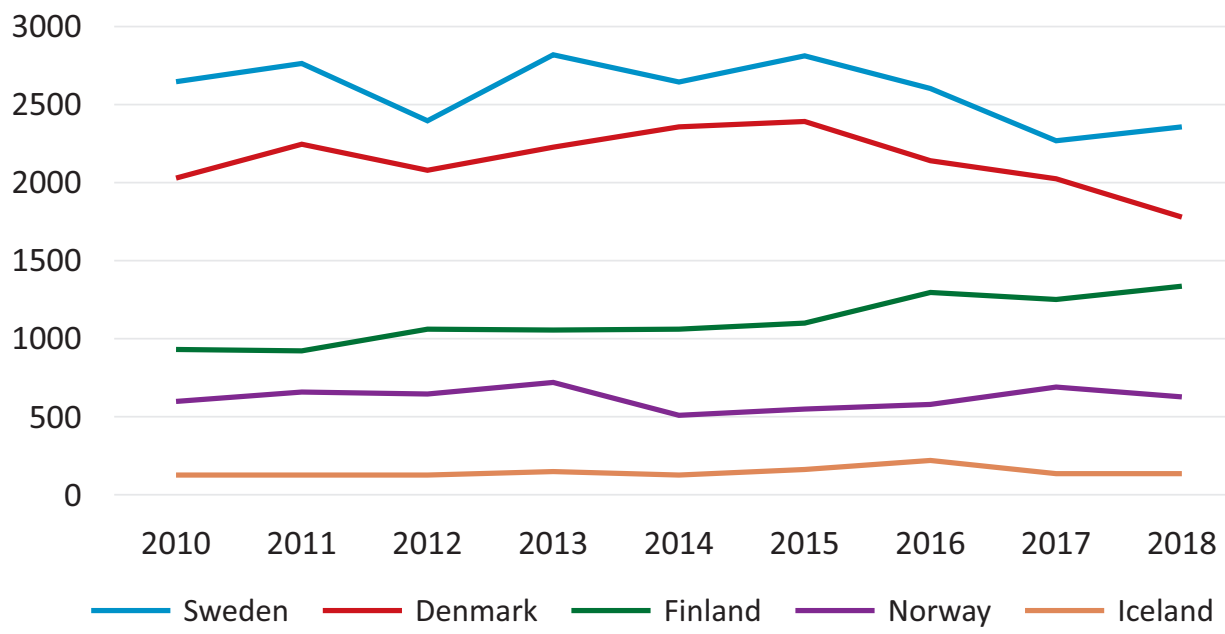

Figure 1. Number of Nordic citizens moving to the UK according to the national statistics data of each sending country, 2010-2018. Sources: Statistics Denmark (2019), Statistics Finland (2019), Statistics Iceland (2019), Statistics Norway (2019), and Statistics Sweden (2019). 
that each follows a particular logic of its own and is an arena for struggles over the specific resources of that field (Wacquant, 1989, pp. 39-40; see also Jenkins, 2002, pp. 84-85).

Habitus refers to the outlook, habits and dispositions embodied onto oneself during socialization; and consists of "schemes of perception, thought, and action" (Bourdieu, 1989, p. 14). It is relevant in the context of migration because a change of cultural and spatial location brings into view social conventions that are usually taken for granted. As Bourdieu noted in an interview with his colleague Loïc Wacquant: "And when habitus encounters a social world of which it is the product, it finds itself 'as fish in water,' it does not feel the weight of the water and takes the world about itself for granted" (Wacquant, 1989, p. 43). The act of migration calls into question the schemes one has learned to live by, as the "water" one must swim in does not conform to one's expectations.

Bourdieu also defined three types of capital: economic, social and cultural. Economic capital refers to a command over economic or monetary resources and social capital refers to resources based on membership of certain networks or groups, such as influence and support. Cultural capital refers to skills and knowledge acquired through education and through the socialisation process (Bourdieu, 1986, pp. 242-243). When the value of these forms of capital is known and recognised either in individual, everyday contexts, or collective, political contexts, they are transformed into symbolic capital, and play a role in the process of societal reproduction (Bourdieu, 1989, p. 17). When migrants cross national borders, they enter a different social sphere, where the types of capital and relations of symbolic power are constructed differently in the various fields that they encounter.

An individual's cultural capital is not a static entity: migrants create new cultural capital in their new country of residence and find ways in which to validate their capital in the new context (Erel, 2010, pp. 649-650) or when they negotiate its value in the local labour market (Csedö, 2008). Migration itself also generates new cultural capital for the migrant in the form of new skills, language competence and experiences of adaptation and learning to manage in different situations. One term used to describe such capital gained during student migration is "mobility capital," which has been defined as a "sub-component of human capital, enabling individuals to enhance their skills because of the richness of the international experience gained by living abroad" (Murphy-Lejeune, 2003, p. 51). Human capital is a concept often used in, for example, economic migration research and discussions on "brain drain" to describe the total of individuals' skills, knowledge and experiences (e.g., Boeri, Brücker, Docquier, \& Rapoport, 2012; Poot, Waldorf, \& van Wissen, 2009). In this study, however, the Bourdieusian approach is preferred as it is more versatile and offers the option of making more nuanced analyses when the transnational networks and resources that are at the migrant's disposal are also taken into account. Therefore, the concept of migrant capital is preferred to that of mobility capital, which has mostly been used in connection with student migration when describing the added value of mobility to one's human capital.

Social capital is the grand total of actual or potential resources that one can mobilise from one's network, group or collective based on solidarity (Bourdieu, 1986, pp. 248-249). For Bourdieu these social networks are not a natural given but must be constructed through investment strategies that aim at institutionalising group relations as a source of benefits (Portes, 1998, p. 3). Anthias (2007) stresses that in the migration context, social capital should refer to social ties and networks that can be mobilised. Ethnic ties may be valuable forms of capital, but their value is often context-dependent and members of these networks are at different positions in how they may take advantage of them in pursuing social advantage. Further, Wahlbeck (2018) argues that an important analytical distinction exits between the transferability and the mobilisability of transnational social resources as network membership does not automatically signify that these ties have significant value. Nowicka (2013) concludes that transnational migrants occupy multiple social positions: they may be embedded in a single space, shift between countries and transnational social spaces and hence encounter many valorisations and conversions of their capital. Also, Erel and Ryan (2019) note that the dynamic process of capital accumulation in the migration context is multi-level and spatio-temporally contingent.

Building on this work, and that of others, I understand migrant capital to consist of two interrelated aspects. These are the new cultural capital of a mobile individual, i.e., the experiences, skills and competence gained during the process of migration, and the economic and social capital and networks that span borders and from which the mobile individual can draw from and contribute towards. How the different aspects of migrant capital play out in each case is highly context-dependent and transnational mobility can add to one's capital in several ways. For example, one's economic capital can increase via remittances sent to family members or investments into the country or origin or via earning significantly higher salaries in the country of destination. For voluntary intra-European migrants originating from affluent, Nordic democracies, sending remittances or striving for economic gain has not typically been the main motivation for migration (e.g., Koikkalainen, 2013). Therefore, in this article, migrant capital is discussed in reference to cultural and social, rather than economic capital.

\section{Data and Methods}

This article is based on qualitative data gathered in 2018-2019 and it examines migration capital through the case of Nordic migrants in London in a contextually and temporally sensitive manner. The aim is not to provide a statistically representative picture of any 
one national group, but rather to learn from their experiences as a group living in London during the Brexitfuelled uncertainty. As the Nordic people in London are not concentrated in any single physical location, the best place to find participants for the study was to turn to the virtual world. Virtual ethnography is a way of doing "ethnographic research in, of and through the virtual" (Hine, 2000, p. 65) and by using the social networks that exist online. The study, therefore, began with a small-scale virtual ethnography tracing the existence of virtual networks and communities that unite Londonbased migrants from Denmark, Finland, Iceland, Norway, and Sweden. The focus was on the online services that distribute job information and on the various virtual discussion groups and websites that distribute "silent knowledge" about living in London. During the period of participant observation, discussions were followed in eight Facebook groups for Scandinavians and Nordic nationals in London and the UK, and a number of blogs, Brexitrelated Twitter debates and online news media reporting.

Then data were collected via an online survey $(\mathrm{N}=164)$ advertised in the Nordic social networks, especially Facebook and Twitter. In addition to asking members of the Facebook groups to take part in the survey, it was also advertised through Facebook advertisements. The survey included questions on the work situation, education, citizenship, partner, children, reasons for migration, identity, international experience, positive treatment versus discrimination, transnational ties, life in London and thoughts about Brexit. Nine of the questions were open-ended. The method of publicising the survey in social media had an impact on the kind of people that took part in the survey. When participants are recruited mainly via one social media platform, one needs to be critical as to the representativeness of the sample in terms of the whole population of interest (Ignacio, 2013). While those who are active members in expatriate Facebook groups are a somewhat select group, using advertising which targeted all Facebook-users with a Nordic background located in London, was a way to diversify the sample when dealing with such a hard-to-reach population (see also Pötzschke \& Braun, 2017). The expatriate communities of the Nordics living in London differ from each other. While the Finnish Facebook groups tend to be active with daily discussions on diverse topics, the groups of Swedes, Norwegians, Icelanders and Danes are less community-like and rather focus on sharing invitations about particular events or information about companies looking for employees skilled in Scandinavian languages, for example. This is one reason why the selection of participants is biased towards Finns, who formed $44 \%$ of all respondents of the survey. Due to the uneven participation of people of the different Nordic nationalities in the survey, no direct comparisons between the countries have been made.

In addition, 15 narrative, in-depth life-historical interviews were conducted with selected survey participants (aged 19 to 39 years) during a fieldwork visit to
London and via Skype. For comparative purposes, the interviews were conducted following the question structure of a European research project titled YMOBILITY, which focused on youth migration in Europe in nine countries (e.g., King \& Williams, 2018; Lulle, Moroşanu, \& King, 2018). Each data type was analysed with slightly different methods. The online textual data, for example, were analysed via a discursive and practice-oriented virtual ethnographic approach (Hine, 2000, pp. 18-19; see also Kozinets, 2010). The survey open-ended responses and interview transcripts have been analysed with narrative content analysis (Spencer, Ritchie, \& O'Connor, 2006, pp. 200-204) to find commonalities in the descriptions of the research participants. To tease out the information relevant to migrant capital, the data were analysed and themes formed from the vantage point of how the Nordic background is visible in their daily lives and careers in London, in their interactions with British society and in light of the ties that still bind them to their respective Nordic countries. In this article, the survey data and the responses to the survey's open-ended questions are the primary forms of data used.

\section{Nordic Migrants in Light of the Survey Data}

Finns were the largest national group in the overall survey data (44\%) followed by Danes (23\%), Swedes (16\%), Norwegians (12\%) and Icelanders (4\%). There is a strong gender bias, as $80 \%$ of all respondents were female and only $20 \%$ male. The participants had diverse migration backgrounds: For some the move to London had been the only form of international mobility, while others had lived abroad before or moved back and forth between the UK and their country of origin. A vast majority of the respondents were still Nordic country citizens (88\%) with the rest holding either Nordic-British, or some other dual nationality. The overall work situation of the respondents was good as $71 \%$ were in full-time employment, while some were working part-time or as freelancers (14\%), were looking for work (4\%), were studying (4\%), were engaged in care work at home (4\%) or were already retired (3\%). The survey respondents were mainly highly educated, as $68 \%$ has either a bachelor's or a master's degree and $7 \%$ had a PhD degree. The rest had a professional degree $(8 \%)$, were still studying $(3 \%)$ or had not completed a degree (14\%).

In migration research, there are three important dimensions of time to consider: age at migration, length of residence in the destination country and age (Stevens \& Ishizawa, 2013). In their study based on migrants of different ethnic backgrounds living in Norway, Erdal and Ezzati (2015) found that age at the time of migration and the relative proportion of life spent in the country of origin and in the settlement country are important factors in migrants' considerations about settlement and return. Also, other studies have found that a migrant's inclusion and the process of embedding in the country of destination changes as time passes (e.g., King \& Mai, 2008; Ryan, 
2018) and as one forms closer bonds with the country of residence.

To analyse the temporal nature of migrant capital, the survey respondents were divided into four groups according to the time they had lived in the UK. The groups were: recent migrants ( $N=41$, in the UK for less than two years), settled migrants ( $N=41$, in the UK for three to nine years), residents ( $N=47$, in the UK for 10 to 19 years) and long-term residents ( $N=35$, in the UK for more than 20 years).

The groups were at different stages of their life course: While the recent and settled migrants are in their twenties and thirties, the residents and long-term residents are in their forties and fifties. In terms of the family situation, in each group as well as in the overall data, those who were married or in a relationship were the majority (68\%). The proportion of singles was highest in the youngest group of recent migrants (41\%) and lowest in the oldest group of long-term residents (23\%). Only $10 \%$ of both migrant groups stated that they have children, while the proportion of those with children is much higher in both resident groups (49\% and $40 \%$ respectively). Key characteristics of each group are detailed in Table 1.

In terms of primary motives for migration, the most common one selected by the participants was for "love" and/or "family" reasons ( $29 \%$ of all respondents) and to study (27\%). In addition, $26 \%$ stated that they moved primarily for reasons related to work or career and $18 \%$ for lifestyle. There was some variation in this respect between the four groups: for the recent migrants and residents the most important motivation was "work" (34\% and $35 \%$ ), whereas for the settled migrants it was "to study" (37\%) and for the long-term residents it was "love" and/or "family" (37\%). One significant difference between the migration experiences of these groups was that the recent migrants moved to the UK either during the Brexit campaign or after the June 2016 EU referendum and were thus aware of the fact that their rights as EU citizens might be at risk due to the Brexit process.

\section{Cultural Capital as Migrant Capital: Skills, Cultural Knowledge and Languages}

Migration can have a positive or negative impact on one's cultural capital depending on how it is valued in the new

Table 1. Key characteristics of the four migrant groups.

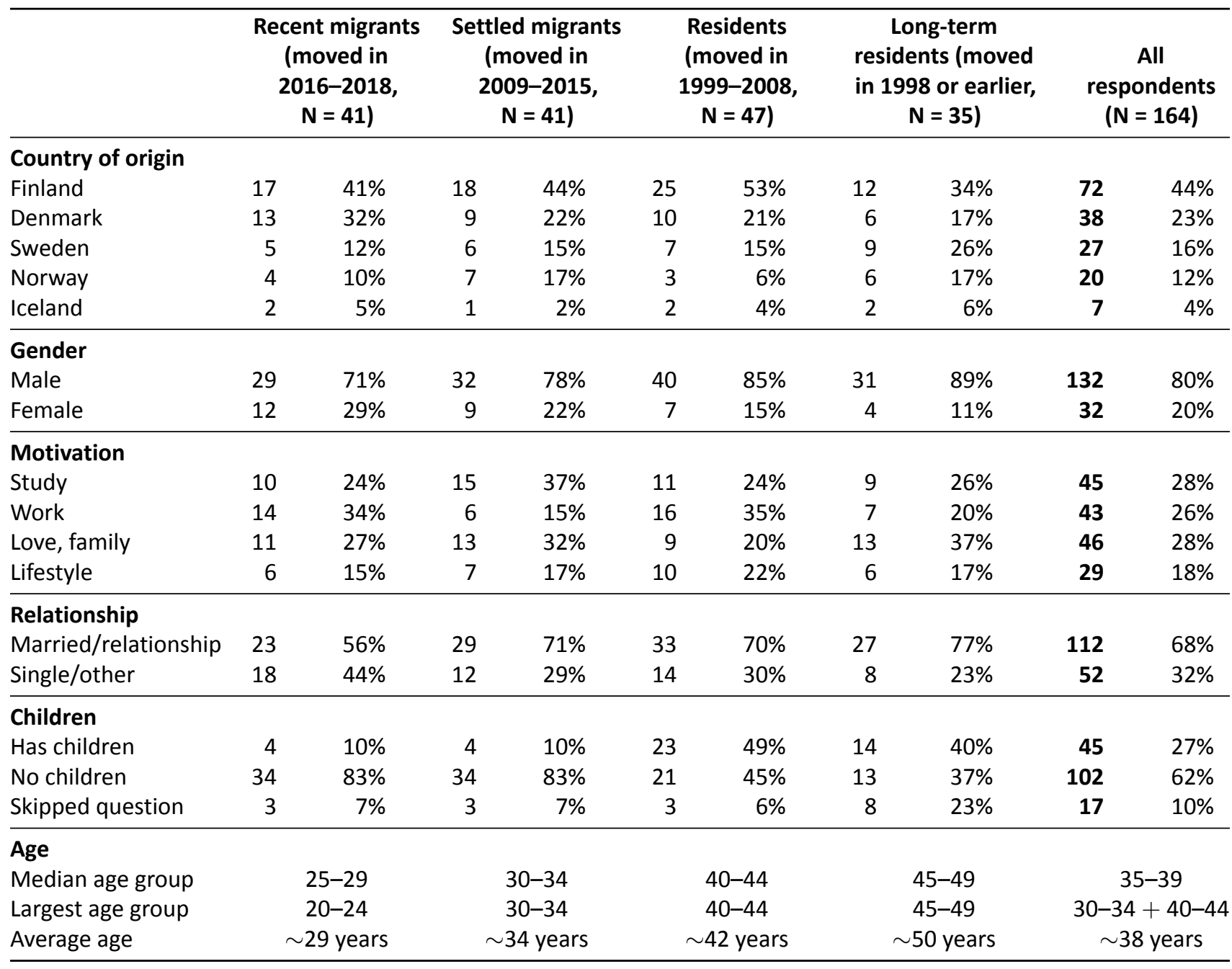


context. For example, the significance of one's previous work experience may not be understood, or a foreign degree might not be fully recognised. In these cases, the migrant might have to accept employment at a lower level than before, continue studying, or look for work in a new field (cf. Koikkalainen, 2014). The situation naturally varies according to the field of employment, as professions differ greatly in how transferable qualifications are across borders. Yet the value of some skills, such as cultural knowledge or competence in relatively uncommon languages, may increase with migration as is evident in the survey data on Nordic migrants. Examples of careers built on languages and cultural competence can be found from all four groups, from recent migrants to long-term residents.

Nordic competence can set newly arrived migrants apart from other job applicants when there is competition over jobs. In response to what it is like to be a Nordic migrant in London, this Norwegian respondent explains:

Easy to get a Norway-related job. As long as you have a good understanding of the Scandinavian languages, it is pretty easy to get into different businesses. Of course, it is competitive but not close to what it would have been being British. I got a job here straight after finishing uni[versity] here and the next job was also another global company. (Female, age 40-45, year of moving to London 2003)

Another quote from a recent Swedish migrant reads: "Well...as I work in a place which contains a lot of flat packs in my language.... it has come quite handy to know the meaning of the names of all that stuff. People do ask about it" (Female, age 40-45, year of moving to London 2017). This also applies to Finnish, which is a member of a different language family from the one that includes Icelandic, Norwegian, Swedish and Danish. A settled migrant from Finland explains: "I've gotten all my jobs so far because I speak Finnish. This has also meant I've ended up in offices with other [Northern] Europeans" (Female, age 30-34, year of moving to London 2013).

For some migrants, the first job gained because of one's Nordic cultural capital was an entry-level job that later led to other jobs that no longer relied on one's migration-related cultural capital. This was the case with the Norwegian professional quoted above who has since worked in two global companies that she thinks would have been hard to get into had she stayed in her native country. Yet some of the long-term residents have built their whole career on their Nordic competence, as this Swedish freelancer explains: "I use the Swedish language in many of the jobs I do, for example, I teach Swedish, I do translation work and I'm a professional tourist guide, working mainly with visitors from Scandinavia" (Female, age 55-59, year of moving to London 1990). In London, a global business hub, there is demand for expertise in the Nordic market as this Icelandic respondent explains: "My work has involved partnering with customers in the
Nordic countries. My language skills-I speak Icelandic and the Scandinavian languages - have been very helpful in my professional life" (Male, age 50-54, year of moving to London 1998).

Skills embodied in one's habitus as a natural part of the cultural capital gained growing up in a Nordic country can thus be an advantage in an environment in which these skills are scarce. Migration also generates other types of cultural capital, i.e., that related to the experiences of adaptation and resilience in starting again in a new country. The four groups examined in this article did not differ from each other significantly in terms of their previous international experience, but there was considerable variation within the groups. For some, the move to the UK was the only noteworthy form of international experience, while others had lived, worked or studied in several countries. An international background opens doors for further mobility and many respondents reflected on the possibility of having to move again due to Brexit. As this Danish respondent concludes:

London is a city like most other European capitals, and I could live in either....Before then I had worked in Greece and Italy and didn't feel like I had to stay in any one place. I was fine to move wherever there would be work. (Female, age 30-34, year of moving to London 2016)

For many, the future was clouded in uncertainty, as the implications of their work situation were not yet known. A Finnish lawyer noted:

Working in the City, my career future in the UK depends on how much of the City is left after Brexit. I'm confident I'll be permitted to stay in the UK, but I'm not going to stay if there aren't jobs for me. I am in a state of permanent insecurity as to my future due to Brexit. (Male, aged 40-44, year of moving to London 2009)

\section{Social Capital as Migrant Capital: Ties, Networks and Resources}

Migration also has an impact on one's social capital, because moving away adds an element of distance to the relationship one has with family, friends and colleagues. However, this does not necessarily signify severing ties with one's social networks or the different types of resources one has access to via these connections. Migrants send and receive money, gifts, knowledge and care across borders via these networks and continue to interact in the social fields that they left behind. Migrants have several types of "transnational social positioning" as the outcome of intersections and conversions of social economic and cultural capital across borders, when lives are lived in multiple locations (Nowicka, 2013, p. 31).

In the case of Nordic migrants in London, monetary transactions across borders are not a significant form 
of interaction, because purely economic motives for migration are rare. Only two respondents among the 164 explicitly stated that money was a factor in moving to London, and both also mentioned other aspects, such as "gaining experience" and "having more work opportunities." Apart from top executives or other highly-paid professionals working in the City, the income levels after living expenses in London are not necessarily that different from the Nordic countries. Thus, migrating for the purpose of sending remittances to family members or to support schooling and care of one's children back home is not an issue with the Nordics. However, the continued participation in transnational social networks is valuable in various ways and may have an impact on one's future mobility choices.

When presented with a list of ten possible ways of interacting with their former home country, the survey respondents selected an average of six ways, the most common ones being "regular visits on holiday," "keeping contact via social media" and "reading online news." In addition, they also keep in touch with their Nordic culture and fellow nationals living in London by speaking their native language, eating Nordic food, meeting friends and hosting visitors from the former home country. The importance of social media networks is especially visible in the Finnish migrant Facebook groups, through which members regularly ask for help and information from their social network. Interestingly, identification with the Nordic home country is high with all the four groups: $76 \%$ of the respondents reported having a strong or very strong identity bond to their respective countries. Perhaps underlining the special nature of London as a world city and a migration destination, respondents in all groups had a stronger identification with the city than with the UK in general. "I am now even more of a Londoner and less of a person living in the UK," explains a Swedish respondent who thinks that "London is simply the greatest city on earth" (Male, age 45-49, year of moving to London 1997). The long-term residents, the group that has lived in the UK for more than 20 years, has understandably the strongest identification with their new home country, as $57 \%$ identify either strongly or very strongly with the UK. This proportion is only $37 \%$ with the most recent migrants, those with less than two years of experience living in London.

Based on the answers to the open-ended questions, Brexit is playing a key role in how the respondents saw the possibility of social inclusion in the UK. A majority were "absolutely gobsmacked," felt "horrified" or were "in shock" when they heard about the referendum result and began to worry about what it would mean for them as residents of the country. For many, the result felt like a betrayal as this Danish respondent explains: "It's difficult to identify with a country that is so polarised and doesn't want EU citizens here, hence [this is] why I will also leave the UK" (Female, age 40-44, year of moving to London 1998). Some of the recent migrants explicitly stated that the timing of their move was influenced by the situa- tion, like this Finnish respondent working in the finance industry who stated: "I did see this as a last chance to move before Brexit" (Female, age 25-29, year of moving to London 2017). She says that she was upset about realising that "up to $52 \%$ of Brits think [she] shouldn't be [there]." Having completed her university degree in the UK she is fairly settled in the social field there and has been moving between Finland and the UK since 2010. At the time of the survey, she was planning to leave the UK before Brexit happens. She explains: "I used to think that London was the greatest city on earth but now I think that title probably goes to Berlin."

\section{Discussion}

The concepts of cultural, social and economic capital are valuable for an analysis of the migration processes in several ways. For example, one can analyse how the mobile individual makes the best possible use of their cultural capital in new surroundings, interacts in the transnational social space between the country of origin and destination and gains social capital and then manages to turn these assets into monetary form as economic capital. Cederberg $(2015$, p. 46$)$ notes that in migration contexts, the different forms of capital are intertwined in numerous ways as cultural capital can at times be converted into social capital by providing access to valuable social resources, and embodied cultural capital is reproduced in social networks. Together, the different forms of capital of an individual contribute towards the sum total of their symbolic capital, which Jenkins (2002, p. 85) simply defines as "prestige and social honour." The power drawn from possessing the right types of symbolic capital, in turn, contributes in legitimating our social world, as "objective relations of power tend to reproduce themselves in relations of symbolic power" (Bourdieu, 1989, p. 21).

For Nordic migrants, the value of their cultural capital in the migration context is generally well recognised, at least if the migrant is willing and able to utilise his or her background effectively. Koikkalainen (2014) defines three strategies that migrants in such situations can adopt when looking for work and trying to get the best possible value for their cultural capital abroad. The somewhat overlapping strategies are: simple adaptation to the rules of the local labour market, distinction based on one's rare and marketable skills and reorientation to look for work in a new field. The Nordic migrant groups in the UK are too small to constitute ethnic neighbourhoods or large ethnic economies (Light \& Gold, 2000) or ethnically defined migration industries (Garapich, 2008) that provide entry-level jobs and drive further migration. Yet, for many of the study participants, the skills and contacts related to their Nordic background had been enough to make them distinct enough to manoeuvre in the London labour market.

Many survey respondents stated that they have never felt discriminated against, they felt privileged in 
comparison with other migrant groups and could even benefit from the fact that they are foreign. These experiences are related to a Nordic stereotype or what Weinar and Klekowski von Koppenfels (2019) call "country label": a set of beliefs relating to a perceived high or low status of a particular country, what its citizens are like, and what the education level in the country is. The significance of Nordic migrants' social capital in the migration context lies mainly in cultural ties and the prospects for mobility in the future. There are no major transfers of monetary resources at present, apart from some investing in property abroad to secure their options to return or onward migrate. Yet Nordic networks both in the UK and in their country of origin are used as a form of everyday transnationalism to gain information, share experiences and teach the Nordic languages and cultural practices to their British-born children.

Despite the status of relative privilege as a migrant group, the uncertainty caused by the Brexit process has already had an impact on the lives of Nordic migrants. The four groups analysed in this article differed in their intentions to stay in the UK. A majority in each group thought they would stay in the UK during the next three years, but the proportions of those likely to stay are higher the longer the individuals had lived in the country. Fifty-one percent of the recent and $56 \%$ of the settled migrants thought staying in the UK was likely, while $74 \%$ of the residents and $77 \%$ of the long-term residents thought the same. The figures follow a similar pattern when the respondents evaluate their life in five years' time: Only $24 \%$ of the recent and $32 \%$ of the settled migrants estimated that they would stay, whereas $40 \%$ of the residents and $51 \%$ of the long-term residents thought this was likely. Thinking about return migration is the highest in the recent migrant group (20\%) as is the proportion of those who were unsure where they would be living in three years' time (20\%).

\section{Conclusion}

The natural experiment currently underway in Europe in the form of Brexit is an excellent case of when the macro level (the politics of Brexit) and the micro level (the experiences of intra-European migrants) should not be studied separately, but rather as interlinked processes unfolding in rich and unpredictable ways. In a similar vein, Erel and Ryan (2019, p. 249) argue that "research should look at the formation of migrants' capitals through the microlevel of personal narratives, the meso-level of networks and the macro-level of structural factors, such as changing global, national and transnational socio-economic and political relations and conditions." For the Nordics, as citizens of affluent European countries with strong market and cultural ties to the UK, the impact of positive stereotyping and cultural trends labelled "Nordic cool" or "Scandimania" in the British media, has created a niche in the labour market as well as a sense of being welcome. With the risk of engaging in methodological nationalism
(Wimmer \& Glick Schiller, 2002) with highlighting the experience of one particular migrant group it can be stated that Nordic migrants are generally well accepted in the UK and able to feel that they belong to the country-or did so at least until the uncertainty following the Brexit referendum in 2016.

The public discourse on Brexit has led to a quasinationalistic invocation of community into the social imagination, in which in the everyday understandings of inclusion and of deciding who is a rightful autochthonous member of the British society are stressed (Cassidy et al., 2018 , p. 191). In the narratives of the residents and longterm residents, who have lived in the UK for decades, many go along with this pressure and talk of their contributions for the benefit of the UK, such as paying taxes and raising new British citizens, thanks to which they should be entitled to belong. Like this Danish respondent explains:

Brexiteers have told me to shut up and go home to my own country as the issue of Brexit is only to be discussed and decided by British people....Ever since I came to the UK I have worked and paid taxes, but now I am not allowed an opinion about the future of the UK? (Male, Danish, age 50-54, year of moving to London 2007)

For the recent migrants and settled migrants, the idea of not being welcome is perhaps less heart-breaking and many have stated that they sympathise with the British people who have nowhere to go if the country ends up in chaos. In the words of another Danish migrant: "I was worried how it was going to affect my rights in the UK. But actually, I felt even more sorry for the Brits and the unsettling situation they are finding themselves in now" (Female, age 20-24, year of moving to London 2016).

Because the scope of this article does not allow for a comparison with other migrant groups, it is difficult to say what, if anything, is unique to the experience of Nordic migrants in London. Examining how the changing situation is experienced by other nationalities in London would add to our understanding of how other variables, such as education levels, employment sectors, race and class have an impact on how Brexit is perceived and how migrant capital is useful for life in a global city. For the Nordic migrants living in London, migrant capital consists first and foremost of cultural and social capital. For them, the Nordic background is valuable thanks to the cultural capital embodied in their habitus as well as the social capital available via the Nordic networks in UK and transnationally. Both these aspects are present regardless of how long the migrant has been living in the UK, even though a longer stay in the country signifies more attachment and ties in the UK. Thus, their migrant capital it is beneficial in terms of achieving social inclusion both in the UK and as a way of possibly migrating abroad if Brexit makes life too difficult for Nordic migrants in the UK. 


\section{Acknowledgments}

The research has received funding from the Academy of Finland project "Transnationalism as a Social Resource among Diaspora Communities" (Grant no. 295417), from the Alfred Kordelin Foundation, Kansan sivistysrahasto and the Kone Foundation. My sincere thanks to these research funders, to the anonymous reviewers of the article and to Dr. Nicol Foulkes-Savinetti for her collaboration in conducting the survey.

\section{Conflict of Interests}

The author declares no conflict of interests.

\section{References}

Anthias, F. (2007). Ethnic ties: Social capital and the question of mobilisability. The Sociological Review, 55(4), 788-805.

Boeri, T., Brücker, H., Docquier, F., \& Rapoport, H. (Eds.). (2012). Brain drain and brain gain: The global competition to attract high-skilled migrants. Oxford: Oxford University Press.

Botterill, K., McCollum, D., \& Tyrrell, N. (2019). Negotiating Brexit: Migrant spatialities and identities in a changing Europe. Population, Space \& Place, 25(1). https://doi.org/10.1002/psp.2216

Bourdieu, P. (1984). Distinction. A social critique of the judgement of taste. Cambridge, MA: Harvard University Press.

Bourdieu, P. (1986). The forms of capital. In J. G. Richardson (Ed.), Handbook for theory and research for the sociology of education (pp. 241-258). New York, NY: Greenwood.

Bourdieu, P. (1989). Social space and symbolic power. Sociological Theory, 7(1), 14-25. Retrieved from https://www.jstor.org/stable/202060

Carmel, E., \& Cerami, A. (2011). Governing migration and welfare: Institutions and emotions in the production of differential integration. In E. Carmel, A. Cerami, \& T. Papadopoulos (Eds.), Migration and welfare in the new Europe. Social protection and the challenges of integration (pp. 1-20). Bristol: Policy Press.

Cassidy, K., Innocenti, P., \& Bürkner, H.-J. (2018). Brexit and new autochthonic politics of belonging. Space and Polity, 22(2), 188-204. https://doi.org/10.1080/ 13562576.2018 .1505490

Cederberg, M. (2015). Embodied cultural capital and the study of ethnic inequalities. In L. Ryan, U. Erel, \& A. D’Angelo (Eds.), Migrant capital: Networks, identities and strategies (pp. 33-47). New York, NY: Palgrave Macmillan.

Csedö, K. (2008). Negotiating skills in the global city: Hungarian and Romanian professionals and graduates in London. Journal of Ethnic and Migration Studies, 34(5), 803-823.

Erdal, M. B., \& Ezzati, R. (2015). 'Where are you from' or 'when did you come'? Temporal dimensions in migrants' reflections about settlement and return. Ethnic and Racial Studies, 38(7), 1202-1217. https://doi. org/10.1080/01419870.2014.971041

Erel, U. (2010). Migrating cultural capital: Bourdieu in migration studies. Sociology, 44(4), 642-660. https:// doi.org/10.1177/0038038510369363

Erel, U., \& Ryan, L. (2019). Migrant capitals: Proposing a multi-level spatio-temporal analytical framework. Sociology, 53(2), 246-263. https://doi.org/10.1177/ 0038038518785298

Favell, A. (2008). Eurostars and Eurocities: Free movement and mobility in an integrating Europe. Oxford: Blackwell.

Garapich, M. P. (2008). The migration industry and civil society: Polish immigrants in the United Kingdom before and after EU enlargement. Journal of Ethnic and Migration Studies, 34(5), 735-752. https://doi.org/ $10.1080 / 13691830802105970$

Guma, T., \& Dafydd Jones, R. (2019). “Where are we going to go now?" European Union migrants' experiences of hostility, anxiety, and (non-)belonging during Brexit. Population, Space \& Place, 25(1). https:// doi.org/10.1002/psp.2198

Hine, C. (2000). Virtual ethnography. London: Sage.

Ignacio, E. N. (2013). The challenges of online diaspora research. In S. J. Gold, \& S. J. Nawyn (Eds.), The Routledge international handbook of migration studies (pp. 522-529). Abingdon: Routledge.

Jenkins, R. (2002). Pierre Bourdieu. Key sociologists. London: Routledge.

King, R., \& Mai, N. (2008). Out of Albania: From crisis migration to social inclusion in Italy. London: Berghahn Books.

King, R., \& Williams, A. M. (2018). Editorial introduction: New European youth mobilities. Population, Space and Place, 24(1). https://doi.org/10.1002/psp.2121

Koikkalainen, P. (2011). Social inclusion. In M. Bevir (Ed.), The Sage handbook of governance (pp. 454-468). London: Sage.

Koikkalainen, S. (2013). Making it abroad. Experiences of highly skilled Finns in the European Union labour markets. Acta Electronica Universitatis Lapponiensis, 134. Rovaniemi: Lapland University Press.

Koikkalainen, S. (2014). Strategies for transferring cultural capital: The case of highly skilled Finns in Europe. Journal of Finnish Studies, 17(1/2), 155-179.

Kozinets, R. V. (2010). Netnography. Doing ethnographic research online. London: Sage.

Light, I., \& Gold, S. (2000). Ethnic economies. London: Academic Press.

Lulle, A., Moroşanu, L., \& King, R. (2018). And then came Brexit: Experiences and future plans of young EU migrants in the London region. Population, Space and Place, 24(1). https://doi.org/10.1002/psp.2122

Murphy-Lejeune, E. (2003). Student mobility and narrative in Europe. The new strangers. London: Routledge. https://doi.org/10.4324/9780203167038 
Nowicka, M. (2013). Positioning strategies of Polish entrepreneurs in Germany: Transnationalizing Bourdieu's notion of capital. International Sociology, 28(1), 29-47. https://doi.org/10.1177/0268580912 468919

Office for National Statistics. (2019a). Annual population survey estimates for nationality and country of birth by sex resident in the UK, 2004 to 2015. Office for National Statistics. Retrieved from https://www.ons. gov.uk

Office for National Statistics. (2019b). Migration statistics quarterly report statistical bulletins: May 2019. Office for National Statistics. Retrieved from https:// www.ons.gov.uk

Poot, J., Waldorf, B., \& van Wissen, L. (Eds.). (2009). Migration and human capital. Cheltenham: Edward Elgar Publishing.

Portes, A. (1998). Social capital: Its origins and applications in modern sociology. Annual Review of Sociology, 24, 1-24.

Pötzschke, S., \& Braun, M. (2017). Migrant sampling using Facebook advertisements: A case study of Polish migrants in four European countries. Social Science Computer Review, 35(5), 633-653. https://doi.org/ $10.1177 / 0894439316666262$

Ryan, L. (2011). Migrants' social networks and weak ties: Accessing resources and constructing relationships post-migration. The Sociological Review, 59(4), 707-724.

Ryan, L. (2018). Differentiated embedding: Polish migrants in London negotiating belonging over time. Journal of Ethnic and Migration Studies, 44(2), 233-251. https://doi.org/10.1080/1369183X.2017. 1341710

Spencer, L., Ritchie, J., \& O'Connor, W. (2006). Analysis: Practices, principles and processes. In J. Ritchie \& J. Lewis (Eds.), Qualitative research practice. A guide for social science students and researchers (pp. 199-218). London: Sage.

Statistics Denmark. (2019). Migrations to and from Denmark. Statistics Denmark. Retrieved from http://www.dst.dk/en/Statistik/emner/befolkning- og-valg/flytninger/flytninger-til-og-fra-udlandet

Statistics Finland. (2019). Migration. Statistics Finland. Retrieved from https://www.stat.fi/til/muutl/index_ en.html

Statistics Iceland. (2019). External migration. Statistics Iceland. Retrieved from https://statice.is/statistics/ population/migration/external-migration

Statistics Norway. (2019). Migrations. Statistics Norway. Retrieved from https://www.ssb.no/en/statbank/ list/flytting

Statistics Sweden. (2019). Population statistics. Statistics Sweden. Retrieved from https://www.scb.se/ en/finding-statistics/statistics-by-subject-area/ population/population-composition/populationstatistics

Stevens, G., \& Ishizawa, H. (2013). Considering time in analyses of migration. In S. J. Gold, \& S. J. Nawyn (Eds.), The Routledge international handbook of migration studies (pp. 522-529). Abingdon: Routledge.

Talani, L. S. (2018). Brexit and the city of London. The revenge of the ultraliberals? In P. Diamond, P. Nedergaard, \& B. Rosamond (Eds.), The Routledge handbook of the politics of Brexit (pp. 49-65). London: Routledge.

Wacquant, L. J. D. (1989). Towards a reflexive sociology: A workshop with Pierre Bourdieu. Sociological Theory, 7(1), 26-63. Retrieved from https://www.jstor.org/ stable/202061

Wahlbeck, Ö. (2018). The transferability and mobilisability of transnational resources. The case of Turkish entrepreneurs in Finland. Nordic Journal of Migration Research, 8(4), 237-244. https://doi.org/10. 2478/njmr-2018-0027

Weinar, A., \& Klekowski von Koppenfels, A. (2019). Migration, mobility, integration, segregation-Migrations within the Global North. International Migration, 57(3). https://doi.org/10.1111/imig.12501

Wimmer, A., \& Glick Schiller, N. (2002). Methodological nationalism and beyond: Nation-state building, migration and the social sciences. Global Networks, 2(4), 301-334.

\section{About the Author}

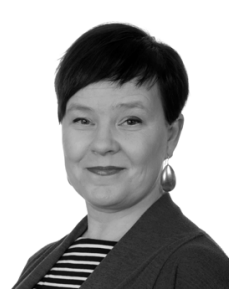

Saara Koikkalainen is a Post-Doctoral Researcher at the University of Helsinki and the leader of the project "Post-Brexit London-Nordic Migrants after the British EU Referendum" (Kone Foundation 2019). Her PhD (2014) focused on the labour market experiences of highly skilled Finns in the EU labour markets. Her research interests include intra-European migration, migration decision-making, and asylum seekers in Finland and her work has been published in, e.g., Nordic Journal of Migration, Journal of Ethnic and Migration Studies and Urban Affairs Review. 